\title{
Ketonaemia in Uncontrolled Diabetes Mellitus
}

\author{
P. J. WATKINS,* M.D., M.R.C.P. ; D. M. HILL, † B.M., M.R.C.P. ; M. G. FITZGERALD, $\ddagger$ M.D., F.R.C.P. \\ J. M. MALINS, $\ddagger$ M.D., F.R.C.P.
}

British Medical fournal, 1970, 4,522-525

Cummary: Blood ketone bodies, serum insulin levels, $\checkmark$ and plasma free fatty acids were examined in a series of patients with "non-ketotic diabetic coma" and compared with the findings in ketoacidotic subjects. Serum insulin levels in six "non-ketotic" patients ranged between 1 and $25 \mu \mathrm{u} . / \mathrm{ml}$. and were not significantly different from levels reported in patients with ketoacidosis. In addition, plasma free fatty acids were shown to be unrelated to the degree of ketonaemia. The investigation shows that neither the levels of serum insulin nor those of free fatty acids can explain the absence of hyperketonaemia in some cases.

\section{Introduction}

Diabetic coma without the characteristic features of Kussmaul respirations or acetone on the breath was reported many years ago (Frerichs, 1883; Stadelmann, 1883; Dreschfeld, 1886), and case reports have appeared intermittently since that time (reviewed by Danowski and Nabarro, 1965; Schwartz and Apfelbaum, 1966). Recently there has been much interest in "non-ketotic diabetic coma" and many attempts have been made to explain it (DiBenedetto et al., 1965; Henry and Bressler, 1968; Maccario and Messis, 1969; R. D. Johnson et al., 1969; Pyke, 1969; Spenney et al., 1969).

The term "ketosis" was first used by Poulton (1918) to describe the specific metabolic acidosis which occurs in uncontrolled diabetes. Precise definition of ketosis should be made by reference to the level of blood ketone bodies, but their measurement has been complex and generally impracticable. The term "non-ketotic" has been carelessly used and in many instances refers to the absence of ketonuria (Danowski and Nabarro, 1965; Halmos et al., 1966). This is not a reliable guide to the ketonaemia, which is better assessed by semiquantitative techniques such as the plasma sodium nitroprusside test using Ketostix (Watkins and FitzGerald, 1968).

The present investigation was undertaken to measure blood ketone bodies in acute diabetic emergencies and to discover the relationship between blood glucose and ketonaemia. Serum insulin and plasma free fatty acids were measured to investigate why some patients develop severe hyperketonaemia and others do not. Diurnal changes of blood glucose, acetoacetates, and free fatty acids in poorly controlled but not ill diabetics were also examined to discover if there is any relationship between them. Recent developments of methods for determining blood ketone bodies by enzymatic (Williamson et al., 1962; Gibbard and Watkins, 1968) and automated (Salway, 1969) techniques have made these investigations possible.

\section{Methods}

Blood acetoacetate was determined by the method of Salway (1969), which uses an AutoAnalyzer to measure both acetoacetate and glucose simultaneously on capillary samples of blood. Blood glucose was determined by the ferricyanide method. The mean blood acetoacetate level in 80 non-diabetic outpatients attending an afternoon ear, nose, and throat clinic was $0.10 \mathrm{mM} \pm 0.02 \mathrm{mM}$ (S.D.). The high normal value

- Senior Registrar, the General Hospital, Birmingham 4.

† Lately Senior Registrar, King's College Hospital, London S.E.5. Now Consultant Physician, Royal Infirmary, Worcester.

₹ Consultant Physician, the General Hospital, Birmingham 4. given by this method reflects its inaccuracy in this range on account of baseline drift that may occur during busy clinics. The reliability of the method above this level has been confirmed by comparison with the enzymatic method of Williamson et al. (1962). Blood 3-hydroxybutyrate levels were measured by the method of Gibbard and Watkins (1968), which is a modification of the enzymatic method of Williamson et al. (1962). The normal fasting level is less than $0.3 \mathrm{mM}$ (Antonis et al., 1966) and probably generally less than 0.1 mM (Jenkins et al., 1970; Williamson, personal communication). Plasma free fatty acids were determined by the colorimetric method of Duncombe (1964) after Dole's (1956) extraction had been performed. The normal range is 0.45 to $0.90 \mathrm{mM}$ (Henry, 1964). Total fatty acids were measured by the method of Stern and Shapiro (1953) (normal value less than $15 \mathrm{mM}$ ) and serum triglycerides by the method of Fletcher (1968) (normal value less than $5.3 \mathrm{mM}$ ). Serum insulin was determined by the immunoassay of Morgan and Lazarow (1963) and in Case 5 by a modification (Sheldon and Taylor, 1965) of the method of Hales and Randle (1963). Blood lactate determinations were made by an enzymatic technique (Gibbard, 1966) and serum cholesterol by an AutoAnalyzer method. Blood acid-base measurements were made with an Astrup microelectrode.

\section{Results}

Blood Glucose and 3-Hydroxybutyrate in Diabetic Coma Patients.- The results of blood glucose and 3-hydroxybutyrate in a series of 39 patients admitted as diabetic emergencies, all requiring intravenous fluids and insulin are given in Fig. 1. No other criteria were used in selection, so that a wide spectrum of ill diabetics could be included in the series. For convenience these patients are described as having "diabetic coma" and subdivided into those with ketoacidosis and non-ketotic patients according to whether or not the hyper-

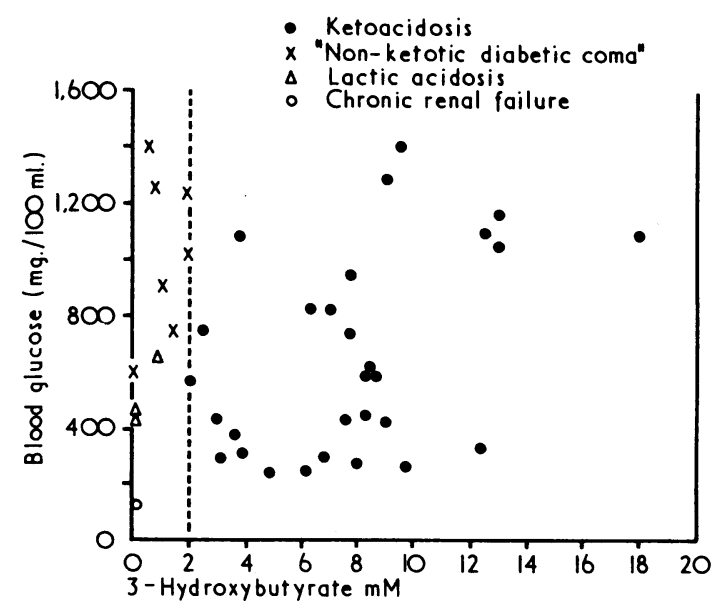

Fig. 1.-Blood glucose and 3-hydroxybutyrate in diabetic emergencies.

ketonaemia was sufficient to cause a metabolic acidosis. $\$$ All patients were admitted to hospital between November 1965 and October 1967 except five non-ketotic patients who have

5 In cases 3 and 8 (Table I) the standard b:carbonate levels were 19.5 and $19.0 \mathrm{mM}$ respectively; these have been included in the series because they had only slight hyperketonaemia. 
TaBle I.-Biochemical Details of Cases 1-9

\begin{tabular}{|c|c|c|c|c|c|c|c|c|c|c|c|c|c|c|}
\hline $\begin{array}{l}\text { Case } \\
\text { No. }\end{array}$ & $\begin{array}{l}\text { Age } \\
\text { and } \\
\text { Sex }\end{array}$ & Race & $\begin{array}{c}\text { Blood } \\
\text { Glucose } \\
(\mathrm{mg} . / 100 \mathrm{ml} .)\end{array}$ & $\begin{array}{l}\text { Blood } \\
\text { 3-HB } \\
(\mathrm{mM})\end{array}$ & $\begin{array}{l}\text { Blood } \\
\text { AcAc } \\
(\mathrm{mM})\end{array}$ & $\mathrm{pH}$ & Pco: & $\mathrm{HCO}_{3}$ & $\begin{array}{l}\text { Blood } \\
\text { Lactate } \\
\text { (mM) }\end{array}$ & $\begin{array}{l}\text { Plasma } \\
\text { Free } \\
\text { Fatty } \\
\text { Acids } \\
(\mathrm{mM})\end{array}$ & $\begin{array}{l}\text { Serum } \\
\text { Total } \\
\text { Fatty } \\
\text { Acids } \\
(\mathrm{mM})\end{array}$ & $\begin{array}{c}\text { Serum } \\
\text { Cholesterol } \\
\text { (mg./100ml.) }\end{array}$ & $\begin{array}{l}\text { Serum } \\
\text { Insulin } \\
\text { ( } \mu \mathrm{u} . / \mathrm{ml} .)\end{array}$ & $\begin{array}{l}\text { Final } \\
\text { Treat- } \\
\text { ment }\end{array}$ \\
\hline $\begin{array}{l}1 \\
2\end{array}$ & $\begin{array}{l}49 \mathrm{M} \\
60 \mathrm{M}\end{array}$ & J. & $\begin{array}{l}900 \\
750\end{array}$ & $\begin{array}{l}0.9 \\
1.4\end{array}$ & $=$ & $\begin{array}{l}7 \cdot 33 \\
7 \cdot 39\end{array}$ & $\begin{array}{l}45 \\
35\end{array}$ & $\begin{array}{l}22 \cdot 0 \\
22 \cdot 0\end{array}$ & 1.0 & $1 \cdot 8$ & $23 \cdot 7$ & 313 & 14 & $\begin{array}{l}\text { Clp } \\
\text { Clp }\end{array}$ \\
\hline 3 & $36 \mathrm{~F}$. & J. & 1,410 & 0.48 & - & $7 \cdot 36$ & 33.5 & 19.5 & 0.9 & 0.75 & $9 \cdot 2$ & 81 & 19 & Ins \\
\hline $4 t$ & $31 \mathrm{M}$. & E. & $\left\{\begin{array}{l}600 \\
675\end{array}\right.$ & 0.09 & - & $7 \cdot 34$ & 46 & $22 \cdot 0$ & - & - & $40 \cdot 0$ & 520 & - & Ins \\
\hline $5^{*}$ & $68 \mathrm{M}$. & E. & $\begin{array}{l}1,013 \\
1,328\end{array}$ & $3 \cdot 8$ & K.S. trace & 7.41 & $\begin{array}{l}27 \\
39\end{array}$ & $\begin{array}{l}1.0 \\
24.0\end{array}$ & $\begin{array}{l}1.1 \\
1.8\end{array}$ & 二 & 20.0 & 247 & $\overline{25}$ & Ins \\
\hline 6 & $49 \mathrm{M}$. & I. & 800 & - & K.S. trace & $7 \cdot 38$ & 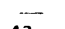 & - & 0.9 & - & - & $\overline{0}$ & - & Ins \\
\hline 7*‡ & $71 \mathrm{M}$. & E. & 1,230 & $1 \cdot 9$ & 0.74 & $7 \cdot 40$ & 43 & $25 \cdot 0$ & - & $1 \cdot 1$ & - & 218 & 4 & Tolb \\
\hline $\begin{array}{l}8^{*} \ddagger \\
9^{*} \neq\end{array}$ & $\begin{array}{l}70 \mathrm{~F} \\
43 \mathrm{~F}\end{array}$ & $\begin{array}{l}\text { E. } \\
\text { J. }\end{array}$ & $\begin{array}{l}1,010 \\
1,055\end{array}$ & $2 \cdot 0$ & $\begin{array}{l}0.83 \\
0.28\end{array}$ & $\begin{array}{l}7 \cdot 34 \\
7 \cdot 35\end{array}$ & $\begin{array}{l}36 \\
46\end{array}$ & $\begin{array}{l}19 \cdot 0 \\
24 \cdot 0\end{array}$ & $=$ & $\begin{array}{l}1.2 \\
1.4\end{array}$ & - & $\begin{array}{l}149 \\
190\end{array}$ & $\begin{array}{l}1 \\
8\end{array}$ & $\begin{array}{l}\text { Clp } \\
\text { Ins }\end{array}$ \\
\hline
\end{tabular}

*New case of diabetes.

†This patient had chronic renal failure and was admitted on two occasions, the first with "non-ketotic coma," the second in ketoacidosis. \$Serum triglyceride levels on admission in Cases 7,8 , and 9 were $17 \cdot 8,13 \cdot 3$, and $18 \cdot 0 \mathrm{mM}$ respectively.

E. = English. J. = Jamaican. I. = Irish

been included since that time. No close relationship between the blood glucose level and ketonaemia has been found, and evidently severe ketoacidosis may occur when hyperglycaemia is not especially pronounced and, conversely, severe hyperglycaemia is sometimes associated with normal blood ketones. Eleven patients had blood 3-hydroxybutyrate levels less than $2 \mathrm{mM}$; three of these had lactic acidosis and one had chronic renal failure, the remaining seven were not acidotic. Full details of non-ketotic patients are given in Table I. Patients whose blood 3-hydroxybutyrate levels were greater than $5 \mathrm{mM}$ were all acidotic and had low blood $\mathrm{pH}$ values, while those in whom the 3-hydroxybutyrate was 2 to $5 \mathrm{mM}$ usually had decreased standard bicarbonate concentrations with a normal blood $\mathrm{pH}$.

Plasma Free Fatty Acids and Blood Acetoacetates in Diabetic Coma Patients.-Plasma free fatty acids and blood acetoacetate levels in five non-ketotic patients (Table I) and a second series of 10 ketoacidotic patients are compared in Table II. The free fatty acids were raised in almost all the non-ketotic patients, and the levels were comparable to those in many of the ketoacidotics. The highest free fatty acid levels (greater than $2 \mathrm{mM}$ ) were, however, seen only in ketoacidosis.

Diurnal Changes in Individual Patients.-The studies shown in Figs. 2 and 3 demonstrate the interrelationship of blood glucose, acetoacetate, and plasma free fatty acids in two patients investigated under similar conditions. They had

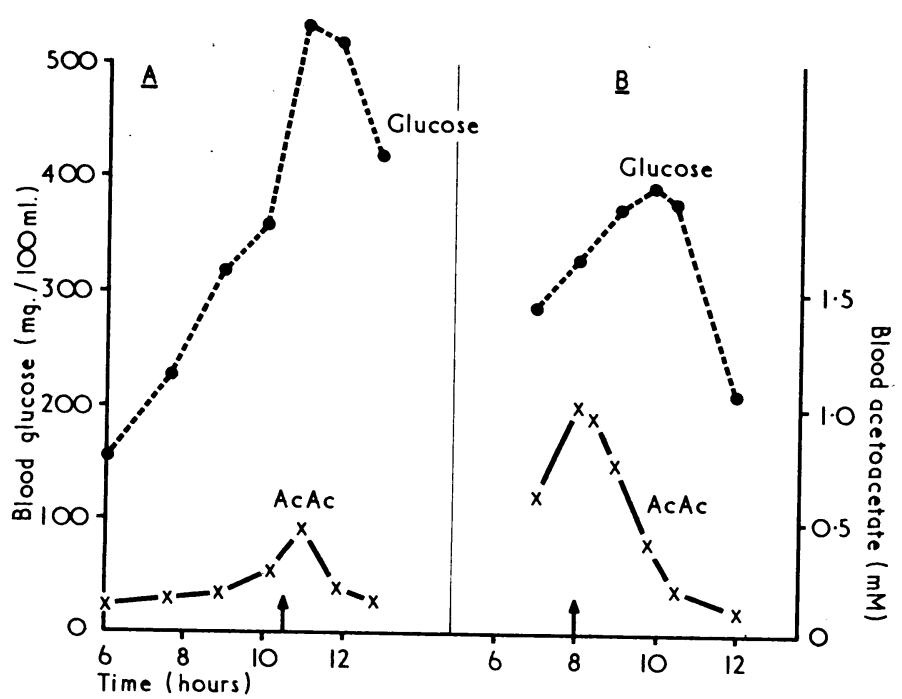

Fig. 2.-Blood glucose and acetoacetate changes in two patients admitted for restabilization of diabetes. Patient A: Women aged 68. Insulin zinc suspension 44 units daily, last given at $8.30 \mathrm{am}$ the previous morning Taking $160 \mathrm{~g}$. carbohydrate diet She had received no food after $10 \mathrm{~m}$. on the previous evening until breakfast at $10.45 \mathrm{~m}$. Patient B. Man p.m. 20. Soluble insulin 64 units in the morning and 40 units dose had been given at $6 \mathrm{p} . \mathrm{m}$. on the previous evening. Taking $240-\mathrm{g}$. carbohydrate diet. He had received no food after 10 p.m. on the previous evening until breakfast at 8.15 a.m.
Table II.-Initial Plasma Free Fatty Acid Levcls and Blood Acetoacetate in Five Non-ketotic Patients Compared with 10 Ketoocidotic Patients

\begin{tabular}{c|c|c|c}
\multicolumn{2}{c|}{ Non-ketotics } & \multicolumn{2}{c}{ Ketoacidotics } \\
\cline { 2 - 4 } \begin{tabular}{c|c} 
Acetoacetate \\
(mM)
\end{tabular} & $\begin{array}{c}\text { Free Fatty } \\
\text { Acids (mM) }\end{array}$ & $\begin{array}{c}\text { Acetoacetate } \\
(\mathrm{mM})\end{array}$ & $\begin{array}{c}\text { Free Fatty } \\
\text { Acids (mM) }\end{array}$ \\
\hline (3-HB 0.48)* & 0.75 & 3.9 & 0.8 \\
0.74 & 1.1 & 2.7 & 1.0 \\
0.83 & 1.2 & 3.2 & 1.0 \\
0.28 & 1.4 & 4.0 & 1.0 \\
& 1.8 & 3.7 & 1.5 \\
& & 2.4 & 1.6 \\
& & 1.5 & 2.1 \\
& & 2.7 & 2.1 \\
& & 1.8 & 2.5 \\
& & 1.9 & 3.0
\end{tabular}

*Only 3-hydroxybutyrate measurements were made in these patients.

received their insulin on the previous day and had their last food at about 10 p.m. The blood glucose of these two patients increased to similar levels before insulin administration (360 and $320 \mathrm{mg} . / 100 \mathrm{ml}$.), but the acetoacetate levels were very different $(0.28$ and $1.0 \mathrm{mM}$, respectively) (Fig. 2). A further increase of the blood glucose in the first patient to $540 \mathrm{mg} . / 100 \mathrm{ml}$. was accompanied by a maximum acetoacetate level of only $0.45 \mathrm{mM}$. Plasma free fatty acids in these patients (Fig. 3) increased to similar levels (1.6 and $1.5 \mathrm{mM}$ respectively) whereas the acetoacetate concentrations were very different $(0.28$ and $1.0 \mathrm{mM})$. In these two patients the plasma free fatty acid level fell rapidly after injection of insulin, while the acetoacetate decreased more slowly (Figs. 2 and 3).

\section{Discussion}

There is no close relationship between blood glucose and blood ketone bodies either in new untreated diabetics (Watkins et al., 1970, unpublished) or in those admitted to hospital as diabetic emergencies (Fig. 1). Severe hyperglycaemia in uncontrolled diabetes is sometimes, but not

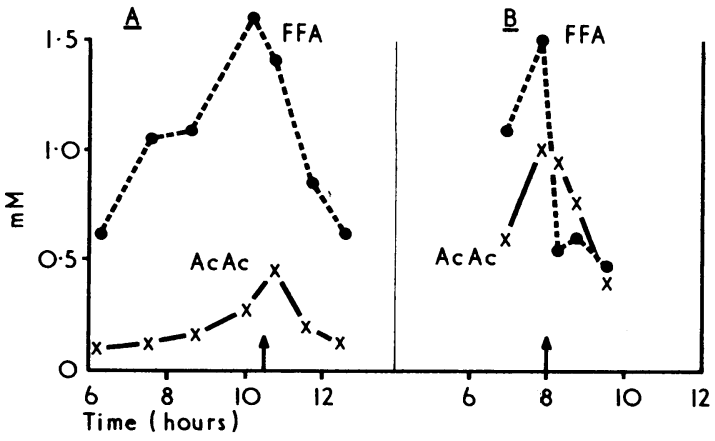

Fig. 3.-Plasma free fatty acid and blood acetoacetate changes in Patients $A$ and $B$, details of whom are given in the caption to Fig. 2. 
always, accompanied by hyperketonaemia, and, conversely, severe ketoacidosis may exist in association with relatively minor rises in the blood glucose. Thus patients do not fall into ketotic and non-ketotic groups but form a continuous series in which every possible combination of blood glucose ard ketonaemia may occur. These observations are not unexpected, because ketogenesis is partly regulated by lipolysis and this depends to a large extent on the rate of glucose utilization, which is not indicated by the blood glucose levels. The association of extreme hyperglycaemia with only slight hyperketonaemia in gravely ill patients is the subject of the present investigation undertaken by examining the relationship of plasma free fatty acids and serum insulin levels to the ketonaemia.

Ketogenesis is stimulated if the circulating free fatty acids are increased from lipolysis. Decreased formation of ketone bodies could theoretically be the result of impaired lipolysis. Since plasma free fatty acid levels may reflect both the rate of production of free fatty acids and determine their rate of uptake by the tissues (Armstrong et al., 1961) one might expect a relationship between plasma free fatty acids and ketonaemia. Several studies have failed to confirm this in vivo (Werk et al., 1961; Azar and Bloom, 1963; Genuth, 1966; Willms et al., 1969), though during a simple fast there appears to be an exponential relationship (Hanson et al., 1965). The present investigations (Table II, Figs. 2 and 3) have confirmed that there is no simple relationship between the actual level of plasma free fatty acids and the ketonaemia. Even in patients with severe ketoacidosis, the plasma free fatty acids were sometimes lower than in other patients with less severe hyperketonaemia. In the non-ketotic patients, plasma free fatty acids were usually raised $(0.75$ to $1.8 \mathrm{mM})$, though the highest levels (more than $2 \mathrm{mM}$ ) occurred only in ketoacidotics. Bewsher et al. (1970) also found raised free fatty acids in two non-ketotic patients. Thus the actual plasma free fatty acid level does not appear to determine the degree of ketonaemia.

Studies of the changes of free fatty acids (Figs. 2 and 3, and many other unpublished studies) show that their increase or decrease usually precedes the changes of the blood ketone bodies and this has been reported by others (Sterky et al., 1966; R. H. Johnson et al., 1969). Their actual levels are not related. Thus though hepatic ketogenesis requires a supply of free fatty acids its rate is not solely determined by their plasma level (Start and Newsholme, 1968). Mayes and Felts (1967) showed that oxidation of fatty acids is greater in livers taken from fasted rats than those from well-fed rats, and the hepatic glycogen content may to some extent regulate the rate of ketogenesis (Courtice and Douglas, 1936). Moreover several of our non-ketotic patients were strongly hyperlipaemic, and both hypercholesterolaemia and hypertriglyceridaemia have been found in some patients (Table I). Bewsher et al. (1970) made similar observations.

The presence of sufficient circulating insulin might inhibit ketogenesis in patients with severe hyperglycaemia. Serum immunoreactive insulin in six non-ketotic patients before treatment ranged between 1 and $25 \mu \mathrm{u} . / \mathrm{ml}$. (Table I). R. D. Johnson et al. (1969) described the case of a patient with serum insulin of $29 \mu \mathrm{u} . / \mathrm{ml}$., and lower values of 5 and 12 $\mu \mathrm{u} . / \mathrm{ml}$. have been reported by Henry and Bressler (1968). On the other hand, serum insulin levels of 5 to $33 \mu \mathrm{u} . / \mathrm{ml}$. in five patients with diabetic ketosis were described by Pyke (1969) and are thus similar to those in the non-ketotic patients. Apparently small amounts of circulating insulin can suppress lipolysis (and therefore ketogenesis) without altering glucose uptake (Zierler and Rabinowitz, 1964), thereby resulting in hyperglycaemia without hyperketonaemia. It remains uncertain why this occurs in some patients and not in others. Indirect evidence for the effective presence of insulin in non-ketotic patients exists, however, in that many of them prove to have mild diabetes which is easily controlled by diet alone or with oral therapy.
The role of diet in determining the rate of ketogenesis may be of considerable importance, and prolonged and very high carbohydrate intake could be one factor responsible for extreme hyperglycaemia with negligible hyperketonaemia. Mirsky et al. (1941) showed that administration of high carbohydrate diets to patients receiving only small amounts of insulin decrease ketonuria while simultaneously increasing blood glucose levels, while Soskin and Levine (1940) showed that tissue glucose uptake can sometimes occur in the absence of insulin if a sufficiently high blood glucose level is maintained. The absence of ketonuria in some West Indian diabetics has been attributed to the ingestion of large quantities of carbohydrate (Tulloch and MacIntosh, 1961), and some "nonketotic diabetic coma" patients have been shown to have had a high carbohydrate intake (DiBenedetto et al., 1965). It is of interest, therefore, that four of the nine non-ketotic patients reported here were West Indians. Carbohydrate intake in a series of new diabetics, however, did not seem to influence the level of the ketonaemia (Watkins et al., 1970, unpublished).

Many other theories have been advanced to explain the low blood ketone levels in some patients, but none seem satisfactory. Thus, treatment with thiazide diuretics (Kumar, 1968; Sølvsteen et al., 1968; Tyler, 1968; Spenney et al., 1969) and hydantoinates (Goldberg and Sanbar, 1969) have been suggested. Jacobs and Nabarro (1969) showed that growth hormone and 11-hydroxycorticosteroid levels in non-ketotic cases are somewhat lower than in ketoacidosis. Moreover, ketoacidosis has been reported in a subject with hypopituitarism (Di Raimondo and Earll, 1968). The present investigation shows that levels of serum insulin and free fatty acid in non-ketotic patients do not explain the varying levels of hyperketonaemia in uncontrolled diabetes.

Two patients (Cases 5 and 6) were in the care of Dr. W. G. Oakley and Dr. D. Pyke at King's College Hospital, London. We are grateful to Miss Jennifer Stevens and Mr. Clive Wulwik for assistance with measurements of lipids and free fatty acids and to $\mathrm{Mr}$. J. Williams, of the Institute of Child Health, Birmingham, for determination of serum insulins.

The work has been helped by a grant from the British Diabetic Association.

\section{REFERENCES}

Antonis, A. Clark, M., and Pilkington, T. R. E. (1966). Fournal of Laboratory and Clinical Medicine, 68, 340 .

Armstrong, D. T., et al. (1961). American fournal of Physiology, $201,9$.

Azar, G. J., and Bloom, W. L. (1963). Archives of Internal Medicine, 112, 338.

Bewsher, P. D., Petrie, J. C., and Worth, H. G. J. (1970). British Medical fournal, 3, 82 .

Courtice, F. C., and Douglas, C. G. (1936). Proceedings of the Royal Society, Series $B, 119,381$.

Danowski, T. S., and Nabarro, J. D. N. (1965). Diabetes, 14, 162.

DiBenedetto, R. J., Crocco, J. A., and Soscia, J. L. (1965). Archives of Internal Medicine, 116, 74

Di Raimondo, V. C., and Earll, J. M. (1968). Diabetes, 17, 147.

Di Raimondo, V. C., and Earll, J. M. (1968). Diabetes, 17, 147

Dole, V.P. (1956). Fournal of Clinical Investigation, 38,

Duncombe, W. G. (1964). Clinica Chimica Acta, 9, 122

Fletcher, M. J. (1968). Clinica Chimica Acta, 22, 393

Frerichs, F. T. (1883). Zeitschrift für klinische Medizin, 6, 1.

Genuth, S. M. (1966). Diabetes, 15, 798.

Gibbard, $S$. (1966). The Application of Enzymes in the Automated Determinations of Oxo- and Hydroxy-acids in Biological Fluids. M.Sc. Thesis, Birmingham

Gibbard, S., and Watkins, P. J. (1968). Clinica Chimica Acta, 19, 511

Goldberg, E. M., and Sanbar, S. S. (1969). Diabetes, 18, 101.

Goldberg, E. M., and Sanbar, S. (1963). Biochemical fournal, 88, 137.

Hales, C. N., and Randle, P. J. (1963). Biochemical fournal, 88, 137.

Hanson, P. G., Johnson, R. E., and Zaharko, D. S. (1965). Metabolism, 14, 1037.

Henry, D. P., and Bressler, R. (1968). American fournal of the Medical Sciences, 256, 150.

Henry, R. J. (1964). Clinical Chemistry, Principles and Technics. New York, Hoeber.

Jacobs, H. S., and Nabarro, J. D. N. (1969). British Medical fournal, 2, 595.

Jenkins, D. J. A., Welborn, T. A., and Goff, D. V. (1970). Lancet, 1, 865. Johnson, R. D., Conn, J. W., Dykman, C. J., Pek, S., and Starr, J. I. (1969). Diabetes, 18, 111.

Johnson, R. H., Walton, J. L., Krebs, H. A., and Williamson, D. H. (1969). Lancet, 2, 1383.

Kumar, R. S. (1968). Lancet, 1, 48. 
Maccario, M., and Messis, C. P. (1969). Lancet, 2, 352.

Mayes, P. A., and Felts, J. M. (1967). Biochemical fournal, 103, 400.

Mirsky, I. A., Franzlau, A. N., Nelson, N., and Nelson, W. E. (1941). fournal of Clinical Endocrinology, 1, 307.

Morgan, C. R., and Lazarow, A. (1963). Diabetes, 12, 115.

Poulton, E. P. (1918). Lancet, 1, 863 .

Pyke, D. A. (1969). Fournal of Clinical Pathology, 22, Suppl. No. 2, p. 57.

Salway, J. G. (1969). Clinica Chimica Acta, 25, 109.

Schwartz, T. B., and Apfelbaum, R. I. (1966). In Year Book of Endocrinology 1965-1966, ed. T. B. Schwartz, p. 165. Chicago, Year Book Medical Publishers.

Sheldon, J., and Taylor, K. W. (1965). fournal of Endocrinology, 33, 157.

Sølvsteen, P., Olsen, V. V., and Hansen, E. L. (1968). Acta Medica Scandinavica, 184, 83.

Soskin, S., and Levine, R. (1940). American fournal of Physiology, 129, 782. Spenney, J. G., Eure, C. A., and Kreisberg, R. A. (1969). Diabetes, 18, 107.
Stadelmann, E. (1883). Archiv für experimentelle Pathologie und Pharmakologie, 17, 419.

Start, C., and Newsholme, E. A. (1968). Biochemical fournal, 109, 37P.

Sterky, G. C. G., Persson, B. E. H., and Larsson, Y. A. A. (1966). Diabetologia, 2, 14

Stern, I., and Shapiro, B. (1953). Fournal of Clinical Pathology, 6, 158.

Tulloch, J. A., and MacIntosh, D. (1961). Lancet, 2, 119.

Tyler, F. H. (1968). American Fournal of Medicine, 45, 485.

Watkins, P. J., and FitzGerald, M. G. (1968). Diabetes, 17, 398.

Werk, E. E., Garber, S., and Sholiton, L. J. (1961). Metabolism, 10, 115.

Williamson, D. H., Mellanby, J., and Krebs, H. A. (1962). Biochemical fournal, 82,90 .

Willms, B., Böttcher, M., Wolters, V., Sakamoto, N., and Söling, H.-D. (1969). Diabetologia, 5, 88.

Zierler, K. L., and Rabinowitz, D. (1964). fournal of Clinical Investigation, 43, 950.

\title{
Effects of Large Doses of Colistin Sulphomethate Sodium on Renal Function
}

\author{
D. J. E. PRICE, ${ }^{*}$ F.R.C.s. ; D. I. GRAHAM,† M.B., B.CH.
}

British Medical fournal, 1970, 4, 525-527

\begin{abstract}
Cummary: High doses of colistin were used in the treat$\checkmark$ ment of severely ill patients with refractory klebsiella chest and urinary tract infections. At the same time renal function was monitored to determine possible nephrotoxicity. In all patients it produced acute renal failure and in some acute tubular necrosis. Though renal failure contributed to the final cause of death in some cases, in the majority death was due to the primary neurological illness.
\end{abstract}

\section{Introduction}

The nephrotoxicity of colistin has been a matter of controversy. In spite of reports of renal damage (Tallgren, Liewendahl, and Kuhlbäck, 1965; Elwood, Lucas, and Muehrcke, 1966), several authors have failed to find any such evidence (Yow, Tan, Shane, Schonfeld, and Abu-Nassar, 1961; Colley and Frankel, 1963; Halliday, 1967).

During a 10-month period in $196830 \%$ of patients in an intensive care unit had klebsiella chest infections and $12 \%$ had urinary tract infections. Eight patients developed klebsiella meningitis (Price and Sleigh, 1970), all of whom died despite appropriate antibiotic therapy. All the strains isolated were sensitive to colistin in vitro, but none of the patients with chest or urinary tract infections responded to colistin in standard dosage (4 mega units per day).

Though we were aware of the possible adverse effects of colistin on renal function, the failure to control the infection with conventional doses led us to increase the dosage sixfold to 26 mega units per day (10 mega units by intramuscular injection, 10 mega units by intravenous injection, and 6 mega units by aerosol inhalation). In the subsequent six-week period the incidence of klebsiella chest and urinary tract infections was halved.

\section{Patients and Investigations}

Fourteen patients aged 31 to 71 years (10 men and 4 women) were treated with high doses of colistin, each receiving 26 mega units per day. Four had a 15-day course, five between one and two weeks, and five less than a week. The mean length of treatment was $\mathbf{9 . 7}$ days. Five of these patients had cerebral abscesses, three had oerebral tumours, four had head injuries, and two had intracranial haemorrhage. Nine of the group were deeply unconscious and four required

\footnotetext{
* Senior Registrar, Department of Neurosurgery. t Lecturer in Neuropathology.
}

The Institute of Neurological Sciences, Glasgow. tracheostomy. Eight had klebsiella tracheobronchitis, one had klebsiella urinary tract infection, and five had both. During and after treatment eight patients died-one with a cerebral abscess, two with malignant tumours, three with head injuries, and two with intracranial haemorrhages. Six of the patients came to necropsy.

Sequential specimens of urine and sputum were examined bacteriologically and the urine was examined for casts. Serum and urine colistin levels, blood urea, serum creatinine, and creatinine clearance rates were determined at the onset of, during, and after treatment.

\section{Results}

Bacteriology.-The organism was eliminated from the sputum in 11 out of 13 patients within a week and from the uri.se of six out of six patients in three days.

Renal Function Tests at Onset of Treatment.-Some patients were dehydrated, but within 24 hours of intravenous fluid therapy none had a blood urea above $45 \mathrm{mg} . / 100 \mathrm{ml}$. or a serum creatinine above $1.4 \mathrm{mg} . / 100 \mathrm{ml}$.

Effects of Colistin on Renal Function.-In all patients a considerable fall in creatinine clearance and rises in both blood urea and serum creatinine levels were observed. Casts appeared in the urine of five patients during the course of treatment. In the six who survived the creatinine clearance rate, serum creatinine, and blood urea returned to within normal limits. On the basis of these findings the patients seemed to fall into two categories. Category 1 (Fig. 1) comprised four patients whose creatinine clearance rate returned to the lower limits of normal within an average of three weeks (19, 30,19 , and 20 days respectively. The graphs of Cases 1 and 4 show the expected rise in serum creatinine as the creatinine clearance rate falls. In Cases 2 and 3 this expected concurrent inverse relationship is not apparent at the time of the greatest reduction in creatinine clearance rate. This was presumably due to faulty collection of 24-hour urine specimens. Category 2 consisted of two patients whose creatinine clearance rate did not return to normal for about nine weeks (60 and 64 days respectively). Full information is available on only one patient (Case 5) (Fig. 2), though the trend was very similar in the second (Case 6 ).

In the eight patients who died during or shortly after treatment there was a similar fall in creatinine clearance rate and a rise in the blood urea and serum creatinine (see Table). In 